\title{
Tax-mediated re-routing of the HTLV-1 p13 protein to nuclear speckles
}

\author{
Vibeke Andresen ${ }^{1}$, Cynthia A Pise-Masison ${ }^{1}$, Uma Sinha-Datta ${ }^{2}$, Robyn Washington Parks', Valentina Cecchinato ${ }^{1}$, \\ Risaku Fukumoto', Christophe Nicot ${ }^{2}$, Genoveffa Franchini ${ }^{1 *}$ \\ From 15th International Conference on Human Retroviruses: HTLV and Related Viruses \\ Leuven and Gembloux, Belgium. 5-8 June 2011
}

Human T-cell Leukemia Virus type-1 (HTLV-1) is highly immunogenic and has low variability so tight regulation of its expression is essential for virus maintenance in vivo. HTLV-1 replication is positively regulated by Tax and Rex, and negatively by the p30 and HBZ proteins. Here, we demonstrate that HTLV-1 encodes another negative regulator of virus expression, the p13 protein. Expressed separately, p13 localizes to the mitochondria, but in the presence of Tax, p13 is stabilized, and re-routed to the nuclear speckles. The p13 protein directly binds Tax, decreases Tax binding to the CBP/ p300 transcriptional co-activator and, by reducing Tax transcriptional activity, suppresses viral expression. These findings suggest that HTLV-1 has evolved a complex mechanism to control its own replication through regulation of positive and negative viral proteins. Further, these results emphasize the importance of studying the function of the HTLV-1 viral proteins, not only in isolation, but also in the context of full viral replication.

\begin{abstract}
Author details
${ }^{1}$ Animal Models and Retroviral Vaccines Section, National Cancer Institute, Bethesda, Maryland, 20892, USA. ²Department of Pathology and Laboratory Medicine, University of Kansas Medical Center, Kansas City, Kansas, 66160, USA.
\end{abstract}

Published: 6 June 2011

doi:10.1186/1742-4690-8-S1-A125

Cite this article as: Andresen et al.: Tax-mediated re-routing of the HTLV-1 p13 protein to nuclear speckles. Retrovirology 2011 8(Suppl 1): A125.

\footnotetext{
* Correspondence: franching@mail.nih.gov

${ }^{1}$ Animal Models and Retroviral Vaccines Section, National Cancer Institute, Bethesda, Maryland, 20892, USA

Full list of author information is available at the end of the article
}

Submit your next manuscript to BioMed Central and take full advantage of:

- Convenient online submission

- Thorough peer review

- No space constraints or color figure charges

- Immediate publication on acceptance

- Inclusion in PubMed, CAS, Scopus and Google Scholar

- Research which is freely available for redistribution

Submit your manuscript at www.biomedcentral.com/submit

\section{() Biomed Central}

\section{Biomed Central}

